\title{
PENGARUH KONSENTRASI BETASIKLODEKSTRIN TERHADAP KELARUTAN GLIMEPIRID
}

\author{
${ }^{1}$ Fitrianti Darusman, ${ }^{2}$ Ulfa Siti \\ 1,2,Program Studi Farmasi, Fakultas MIPA, Universitas Islam Bandung, Jawa Barat, Indonesia \\ email:1'efit.bien@gmail.com
}

\begin{abstract}
ABSTRAK
Glimepirid (GMP) merupakan obat antidiabetika oral golongan sulfonilurea generasi ketiga yang mampu menurunkan kadar glukosa darah dengan efek samping hipoglikemia yang kecil. Namun GMP termasuk ke dalam Biopharmaceutical Classification System (BCS) kelas II yang memiliki kelarutan praktis tidak larut dalam air sehingga berpengaruh pada laju disolusi dan bioavailabilitasnya. Salah satu upaya untuk meningkatkan kelarutan GMP yaitu dengan pembentukan kompleks inklusi menggunakan betasiklodekstrin (BCD). Penentuan terbentuknya kompleks inklusi GMP-BCD menggunakan beberapa konsentrasi larutan BCD yang semakin meningkat dalam dapar asetat $0,01 \mathrm{M} \mathrm{pH} \mathrm{6,2} \mathrm{dan} \mathrm{dapar} \mathrm{fosfat} \mathrm{0,01} \mathrm{M} \mathrm{pH} \mathrm{7,4}$ yang diteliti dengan metode kelarutan dan ditentukan secara spektrofotometri ultraviolet pada panjang gelombang serapan maksimum $228 \mathrm{~nm}$. Hasil penelitian menunjukkan bahwa kelarutan GMP meningkat dengan semakin meningkatnya konsentrasi BCD dengan harga tetapan stabilitas kompleks pada $\mathrm{pH}$ 7,4 lebih sebesar $0,650 \mathrm{M}^{-1}$ lebih besar dari pada $\mathrm{pH} 6,2$ yaitu sebesar $0,237 \mathrm{M}^{-1}$.
\end{abstract}

Kata kunci : glimepirid, betasiklodekstrin, kompleks inklusi, kelarutan.

\begin{abstract}
Glimepiride (GMP) is a third-generation oral antidiabetic drug of sulfonylurea group capable of lowering blood glucose levels with small hypoglycemia side effects. GMP, however, belongs to a class II Biopharmaceutical Classification System (BCS) which has a solubility practically insoluble in water that affects its dissolution rate and bioavailability. One effort to improve GMP solubility is by forming inclusion complexes using betacyclodextrin (BCD). Determination of GMP-BCD inclusion complexes using several concentrations of an increasing BCD solution in $0.01 \mathrm{M}$ acetate buffer $\mathrm{pH} 6.2$ and $0.01 \mathrm{M}$ phosphate buffer $\mathrm{pH} 7.4$ which was investigated by solubility method and determined by ultraviolet spectrophotometry at wavelength maximum absorption of $228 \mathrm{~nm}$. The results showed that the solubility of GMP increased with increasing of BCD concentration with the price of complex stability constant at $\mathrm{pH} 7,4$ over $0,650 \mathrm{M}^{-1}$ bigger than $\mathrm{pH} 6,2$ that is equal to $0,237 \mathrm{M}^{-1}$.
\end{abstract}

Keywords : glimepiride, betacyclodextrin, inclusion complexes, solubility

\section{PENDAHULUAN}

Glimepirid (GMP) merupakan obat antidiabetika oral golongan sulfonilurea generasi ketiga yang mampu menurunkan kadar glukosa darah dengan efek samping hipoglikemia yang kecil. Namun GMP termasuk ke dalam Biopharmaceutical Classification System (BCS) kelas II yang memiliki kelarutan praktis tidak larut dalam air 
Pengaruh Konsentrasi Betasiklodekstrin..

sehingga berpengaruh pada laju disolusi dan bioavailabilitasnya.

Salah satu upaya untuk meningkatkan kelarutan GMP yaitu dengan pembentukan kompleks inklusi menggunakan senyawa turunan siklodekstrin yaitu betasiklodekstrin (BCD) yang memiliki bentuk berongga toroidal) dengan bagian luar rongganya bersifat hidrofilik sehingga mudah larut dalam air dan bagian dalamnya bersifat hidrofobik (Bekers dkk., 1991).

BCD membentuk kompleks inklusi dengan cara "menangkap" molekul obat sebagai guest ke dalam rongganya (Frank, 1975) sehingga merubah sifat fisikokimia dari molekul obat tersebut terutama sifat kelarutan (Bekers dkk., 1991). Persyaratan minimal yang harus dipenuhi oleh molekul obat agar terbentuk kompleks inklusi adalah ukuran dan bentuk molekul obat tepat masuk atau sebagian masuk ke dalam rongga BCD (Rajewski dan Stella, 1996) dan kompleks inklusi yang terbentuk distabilkan oleh gaya-gaya antar molekul, seperti gaya van der Waals, ikatan hidrogen, interaksi hidrofob dan pelepasan air energi tinggi (Bekers dkk., 1991).

Penelitian ini bertujuan untuk melihat pengaruh senyawa BCD pada berbagai konsentrasi yang semakin meningkat terhadap kelarutan GMP sebagai awal penentuan terbentuknya kompleks inklusi GMP-BCD.

\section{METODE PENELITIAN}

\subsection{Alat}

Timbangan analitik (Mettler Toledo AG204), vortex mixer (Thermo Scientific), pengaduk orbital (GFL 1092), pH-meter, magnetic stirrer-hot plate (merk Thermo scientific), dan spektrofotometer UV (Shimadzu UVmini-1240).

\subsection{Bahan}

Glimepirid (Eks PT. Kimia Farma), betasiklodekstrin (Eks PT. Sanbe Farma), dinatrium hidrogen fosfat $\left(\mathrm{Na}_{2} \mathrm{HPO}_{4}\right)$ p.a dan kalium dihidrogen fosfat $\left(\mathrm{KH}_{2} \mathrm{PO}_{4}\right)$ p.a, asam asetat glasial $\left(\mathrm{CH}_{3} \mathrm{COOH}\right)$ p.a, natrium asetat $\left(\mathrm{CH}_{3} \mathrm{COONa}\right)$ p.a dan metanol p.a dan aquadest.

\subsection{Prosedur}

Ke dalam vial $10 \mathrm{ml}$ dimasukan 5,0 ml larutan BCD dengan kadar $0 ; 2,5.10^{-3} ; 5.10^{-3}$; $7,5.10^{-3}, 10.10^{-3} \mathrm{M}$ yang dibuat masing-masing dalam larutan dapar asetat $0,01 \mathrm{M} \mathrm{pH} \mathrm{6,2} \mathrm{dan}$ larutan dapar fosfat $0,01 \mathrm{M} \mathrm{pH} \mathrm{7,4} \mathrm{dengan}$ kekuatan ionik 0,1. Larutan diletakan ke dalam shaker waterbath dan diatur sampai tercapai suhu $37 \pm 0,5^{\circ} \mathrm{C}$. Kemudian ke dalam masingmasing vial dimasukan serbuk GMP sebanyak $50 \mathrm{mg}$ dan dikocok dengan kecepatan 50 putaran/menit selama 3 jam. Setelah 3 jam, larutan diambil kemudian disaring dengan menggunakan kertas Whatman dan ditentukan kadarnya dengan spektrofotometer ultraviolet 
pada panjang gelombang serapan maksimum $228 \mathrm{~nm}$. Percobaan dilakukan pada dua kali replikasi (duplo) (Higuchi, dkk., 1965).

\section{HASIL DAN PEMBAHASAN}

Pada penentuan terbentuknya kompleks inklusi GMP-BCD dengan metode kelarutan digunakan beberapa konsentrasi $\mathrm{BCD}$ yang semakin meningkat dengan tujuan untuk melihat pengaruh peningkatan konsentrasi BCD terhadap peningkatan kelarutan dari GMP. Pengujian ini dilakukan dalam larutan dapar asetat $\mathrm{pH}$ 6,2 dan dapar fosfat $\mathrm{pH} 7,4$. Pemilihan kondisi pH 6,2 didasarkan pada nilai pKa dari GMP yang berdasarkan perhitungan Handerson-Hasselbach pada pH 6,2 jumlah GMP berada dalam bentuk terionkan sebesar $50 \%$. Pemilihan $\mathrm{pH} 7,4$ didasarkan pada kondisi pH netral yang merupakan $\mathrm{pH}$ optimum pelarutan GMP.

Perbandingan jumlah bentuk terion dan tak-terion dari molekul guest akan mempengaruhi interaksi masuknya molekul guest (GMP) yang bersifat hidrofob kedalam molekul host (BCD). Semakin banyak jumlah tak-terion dari molekul guest akan semakin meningkatkan kemungkinan terbentuknya kompleks inklusi guest-host yang dalam hal ini dalah GMP-BCD.

Hasil penentuan terbentuknya kompleks inklusi GMP-BCD yang diteliti dengan uji kelarutan GMP dalam beberapa konsentrasi BCD yang semakin meningkat, dapat dilihat pada tabel dibawah ini :

Tabel 1. Kelarutan Glimepirid dalam Dapar Asetat $\mathrm{pH}$ 6,2 dan 7,4 dengan Beragam Varian Konsentrasi

\begin{tabular}{c|c|c}
\hline \hline \multirow{2}{*}{$\begin{array}{c}\text { Konsentrasi } \\
\mathrm{BCD} \\
\mathrm{M}\left(\mathrm{x} 10^{-3}\right)\end{array}$} & \multicolumn{2}{|c}{ Kelarutan Glimepirid } \\
\cline { 2 - 3 } & $\begin{array}{c}\text { dalam dapar } \\
\text { asetat } \mathrm{pH} 6,2\end{array}$ & $\begin{array}{c}\text { dalam dapar } \\
\text { fosfat } \mathrm{pH} 7,4\end{array}$ \\
\hline \hline 0 & 0,018 & 0,0219 \\
\hline \hline 2,5 & 0,0214 & 0,0595 \\
\hline 5 & 0,0333 & 0,0766 \\
\hline 7,5 & 0,0403 & 0,1164 \\
\hline 10 & 0,0537 & 0.1583 \\
\hline \hline
\end{tabular}

Dari tabel diatas dibuat grafik hubungan antara kelarutan GMP dengan konsentrasi BCD, seperti dibawah ini : 
Pengaruh Konsentrasi Betasiklodekstrin..

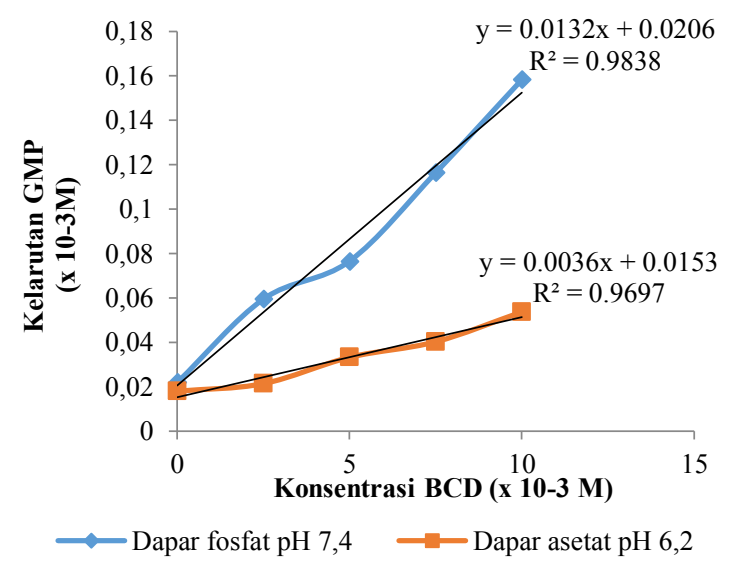

Gambar 1. Grafik hubungan antara kelarutan GMP terhadap konsentrasi BCD

Dari kedua data tersebut terlihat bahwa semakin tinggi konsentrasi BCD yang digunakan maka semakin meningkat kemampuan GMP untuk melarut. Disamping itu nilai slope pada $\mathrm{pH}$ 6,2 yaitu 0,0036 lebih kecil dibandingkan nilai slope $\mathrm{pH} \mathrm{7,4}$ yaitu 0.0132. Nilai slope ini menggambarkan kemampuan GMP membentuk kompleks dengan BCD. Hal ini menunjukkan bahwa kelarutan GMP dalam pH 7,4 lebih besar karena pada $\mathrm{pH}$ 7,4 GMP berada pada bentuk terionkan lebih banyak. Stabilitas kompleks yang didapat dari hasil perhitungan pada $\mathrm{pH}$ 6,2 yaitu 0,2371 dan pada $\mathrm{pH}$ 7,4 yaitu 0,65012. Dapat dilihat dari hasil tersebut semakin tinggi pH maka stabilitas kompleks yang dihasilkan semakin meningkat (Isadiartuti, 2000).

Dari grafik diatas dapat pula dilihat bahwa kurva kelarutan GMP dalam larutan BCD baik pada $\mathrm{pH}$ 6,2 maupun $\mathrm{pH} 7,4$ membentuk kurva kelarutan tipe $A_{L}$ yaitu terbentuk kompleks yang larut dan tidak terjadi pengendapan dengan semakin meningkatnya konsentrasi BCD sehingga dapat dipandang tipe kompleks inklusi yang terbentuk antara GMP dengan BCD terjadi pada perbandingan dengan jumlah molekul BCD yang semakin tinggi daripada jumlah molekul GMP, misalnya pada perbandingan 1:2 (Isadiartuti, 2000).

\section{KESIMPULAN}

Dari penelitian dapat disimpulkan bahwa Betasiklodekstrin mampu meningkatkan kelarutan glimepirid. Dengan semakin meningkatnya konsentrasi betasiklodesktrin semakin meningkat pula kelarutan glimepirid. Harga tetapan stabilitas kompleks pada pH 7,4 lebih besar yaitu 0,65012 daripada harga tetapan stabilitas kompleks pada $\mathrm{pH}$ 6,2 yaitu 0,2371 Kelarutan glimepirid dalam betasiklodekstrin membentuk kurva tipe $A_{L}$.

\section{DAFTAR PUSTAKA}

Anonim, 2014. Farmakope Indonesia, Edisi V, Departemen Kesehatan Republik Indonesia. Jakarta 
Bekers, O., Uijtendaal, E. V., Beijnen, J. H., Bult, A., \& Undenberg, W. J.M., 1991. Cyclodextrin in Pharmaceutical Field, Drug Dev. Ind. Pharm., 17(11): 1503-1549.

Frank, S.G., 1975. Inclusion Compounds, J.Pharm.Sci., 64(10):1567.

Higuchi, T., and Connors, K.A., 1965. Advances in Analytical Chemistry and Instrumentation, 4(117) Interscience, New York.
Isadiartuti, Dewi., Suwaldi., 2000. Pengaruh senyawa hidroksipropil- $\beta$-siklodekstrin terhadap kelarutan Fenobarbital. Majalah Farmasi Indonesia. 11(4): 205-208.

Rajewski, R.A., and Stella, V.J., 1996. Pharmaceutical Application of Cyclodextrine.2.In Vivo Drug Delivery, J.Pharm.Sci., 85(11): 1142-1169. 